Volume 13

\title{
Cultural Impairment and the Genocidal Potential of Intoxicants: Alcohol use in Colonial North America
}

\author{
Elena Lesley \\ Emory University
}

Follow this and additional works at: https://digitalcommons.usf.edu/gsp

\section{Recommended Citation}

Lesley, Elena (2019) "Cultural Impairment and the Genocidal Potential of Intoxicants: Alcohol use in Colonial North America," Genocide Studies and Prevention: An International Journal: Vol. 13: Iss. 1: 88-97. DOI:

https://doi.org/10.5038/1911-9933.13.1.1622

Available at: https://digitalcommons.usf.edu/gsp/vol13/iss1/10

This Articles is brought to you for free and open access by the Open Access Journals at Digital Commons @ University of South Florida. It has been accepted for inclusion in Genocide Studies and Prevention: An International Journal by an authorized editor of Digital Commons @ University of South Florida. For more information, please contact digitalcommons@usf.edu. 


\title{
Cultural Impairment and the Genocidal Potential of Intoxicants: Alcohol Use in Colonial North America
}

\author{
Elena Lesley \\ Emory University \\ Atlanta, Georgia, USA
}

During negotiations over the proposed UN Genocide Convention, a delegate from China suggested that the distribution of drugs be included as a method of genocide. He said that under Japanese occupation during World War II, the Japanese had "imposed mass consumption of drugs in order to disintegrate the minds of the Chinese population ... and make them forget their national aspirations and their craving for national freedom," Lemkin writes in his account of the negotiations. ${ }^{\text {A }}$ Polish delegate concurred, adding that the Nazis had insisted on paying their non-German workers in alcohol in order to undermine Polish society. Lemkin himself raised the issue of psychological damage done to those in concentration camps by the Nazis and decided to focus on the "area of damage rather than the means of action." 2 This led to the inclusion in the Genocide Convention of the intent to cause "serious bodily or mental harm" to members of a group. Thus, although the convention does not make explicit reference to intoxicants, they served as inspiration for one of its main clauses. Moreover, in Lemkin's writings on genocide, intoxicants certainly emerge as a subject of concern, and as a method of genocidal conquest. This may seem puzzling to many modern readers, raised with a conception of genocide as state-organized mass killing. But the man who coined the term "genocide" actually developed a conception of genocide that differs significantly from the UN Convention itself, and from the popular understanding that has been influenced by the convention. Notes related to his thinking on the subject are included in his unfinished work housed at the New York Public Library and the American Jewish Historical Society, where the author conducted research in relevant archives.

In his writings, Lemkin privileged the natural right of groups to exist, believing that certain forms of human collectivities -- national, racial, religious and ethnic - were especially valuable because they made unique contributions to broader human civilization. ${ }^{3}$ He paid particular attention to the importance of nations as "families of mind," or "aspects of consciousness that took on a social reality ... between individuals." ${ }^{4}$ Drawing on the work of Frazer and Malinowski regarding cultural functionalism, he saw culture as the undergirding force that enabled nations to survive and provide for the basic needs of the individuals of which they were composed. Actions that undermined the cohesiveness of a group's culture challenged the existence of the group itself - and by extension, of its members, which relied on the bonds of culture to fulfill both their basic and derived needs. As a result, genocide could take place without recourse to physical violence. Lemkin considered a broad range of acts genocidal, such as destroying cultural symbols, removing children from their group of origin and, as will be examined in this paper, the widespread distribution of intoxicants. For groups such as the Native Americans and Tasmanians, Lemkin believed that the introduction of new substances by colonists served as a disruptive influence on cultural functioning. Unaccustomed to the effects of alcohol, indigenous people would, "under the influence of intoxication ... in a fit of unbridled frenzy, murder friend, kin and even wife or offspring without distinction," Lemkin wrote. ${ }^{5}$ Alcohol led to internal social strife, a decrease in births and prohibited women from properly caring for their children, Lemkin believed. Moreover, intoxicants undermined the psychological stability of human groups and, "when the minds are destroyed, the cohesive force of the group, which is essentially of a mental quality, cannot be produced." ${ }^{\prime}$

\footnotetext{
${ }^{1}$ Raphaël Lemkin, “Writings-Autobiography,” n.d. Raphaël Lemkin Papers, Manuscript Collection 1730, Manuscript and Archives Division, New York Public Library, New York, U.S. (hereafter NYPL), Reel 2, Box 1, n.p. ${ }^{2}$ Ibid.

${ }^{3}$ A. Dirk Moses, "Raphaël Lemkin, Culture and the Concept of Genocide," in The Oxford Handbook of Genocide Studies, ed. Donald Bloxham and A. Dirk Moses (New York: Oxford University Press, 2010), 23.

${ }^{4}$ Douglas Irvin-Erickson, Raphaël Lemkin and the Concept of Genocide (Philadelphia: University of Pennsylvania Press) 221.

${ }^{5}$ Raphaël Lemkin, “North American Indians - Extermination,” 1948-1949, Research Index Cards, Raphaël Lemkin Collection, American Jewish Historical Society (hereafter AJHS), Box 9, Folder 13, Card 11.

${ }^{6}$ Lemkin, Writings-Autobiography.
}

Elena Lesley. "Cultural Impairment and the Genocidal Potential of Intoxicants: Alcohol Use in Colonial North America" Genocide Studies and Prevention 13, 1 (2019): 88-97. @2019 Genocide Studies and Prevention. 
At the same time, even as Lemkin suggested that distribution of intoxicants constituted a form of genocide, his writings encounter several theoretical snags. He wrote that destruction of culture was genocidal only when undertaken with the intent to destroy the nation, or "family of mind."7 While the archives show that Lemkin made significant note of the various ways in which intoxicants disrupted Native American communities, there is less material devoted to proving a specific intent to destroy native "families of mind" through these means. In addition, the historical material from which he drew sometimes falls into the trap of "intellectual colonialism," 8 characterizing Native Americans as inherently weak and undisciplined. Thus, while Lemkin's work on the subject remains important as it highlights the multiple ways in which colonial oppression can operate, he fell short of making a holistic case for alcohol distribution as a specifically genocidal method of conquest.

\section{Settler Colonialism and Genocide}

Lemkin's belief in the functional importance of culture for human groups informed his concern for conquered and oppressed peoples. While the Holocaust has emerged as the paradigmatic case of genocide in popular consciousness, numerous scholars in critical genocide studies have argued that colonialism was central to Lemkin's definition of genocide. ${ }^{9}$ Starting in the early 2000s, genocide studies has taken "colonial turn," as scholars found Lemkin's original formulation of the concept a useful tool for examining the multiple ways in which genocide can operate. ${ }^{10}$ In his often-quoted passage from Axis Rule in Occupied Europe, Lemkin wrote that genocide has two phases: "one, destruction of the national pattern of the oppressed group; the other, the imposition of the national pattern of the oppressor." ${ }^{11}$ After such destruction, the national pattern could be imposed either on the natives, who were allowed to remain, or on the territory itself once the natives had been removed from the land. Thus, Lemkin's conception of genocide involved conquest that "aimed to permanently tip the demographic balance in favour of the occupier." 12 As Moses writes, Axis Rule is less a meditation on genocide itself, and more a description of genocide as one of many tools of German occupation. Even if Germany were to be militarily defeated, the Nazis had set out to "destroy or cripple the subjugated peoples" so that post-war society would nevertheless be dominated by German culture, according to Lemkin. ${ }^{13}$ In the cases of indigenous peoples, Lemkin's definition can help demonstrate how indigenous people became ensnared within a web of colonial settler policies, such as forced relocations and the placement of children in state-run boarding schools ${ }^{14}$

It should be noted, however, that Lemkin did not oppose all forms of imperialism. Like Malinowski, he believed that cultural diffusion in humanely governed empires could improve more "primitive" cultures, as "weaker societies adopt the institutions of more efficient ones or become absorbed by them because they better fulfill basic needs." ${ }^{15}$ In this way, Lemkin was able to justify the disappearance of numerous civilizations over time, without labeling their decline as genocidal. For him, the main question was the extent to which a stronger culture was violently enforced from above; a more indirect diffusion, or "trickle down" effect, was perhaps regrettable in a nostalgic kind of way, but inevitable when weaker civilizations encountered more "advanced" and efficient cultures.

\footnotetext{
${ }^{7}$ Irvin-Erickson, Raphäl Lemkin and the Concept of Genocide, 221.

${ }^{8}$ Gilbert Quintero, "Making the Indian: Colonial Knowledge, Alcohol and Native Americans," American Indian Culture and Research Journal 25, no. 4 (2001), 57-71.

${ }^{9}$ Michael A. McDonnell and A. Dirk Moses, "Raphaël Lemkin as Historian of Genocide in the Americans," Journal of Genocide Research 7, no. 4 (2005), 501.

${ }^{10}$ Jeff Benvenuto et al, "Colonial Genocide and Indigenous North America," in Colonial Genocides in Indigenous North America, ed. Andrew Woolford et al. (Durham: Duke University Press, 2014).

${ }^{11}$ Raphaël Lemkin, Axis Rule in Occupied Europe (Washington, DC: Carnegie Endowment for International Peace, 1944$), 80$.

${ }^{12}$ Moses, Raphaël Lemkin, 26.

${ }^{13}$ Ibid., 32.

${ }^{14}$ Andrew Woolford and Jeff Benvenuto, “Canada and Colonial Genocide," Journal of Genocide Research 17, no. 4 (2015), 373-390.

${ }^{15}$ Moses, Raphaël Lemkin, 27.
} 
The process of permanently crippling a culture could be achieved through a variety of tactics. Killing members of the group was one potential method, Lemkin wrote, but so were preventing births, forcible relocations and destruction of cultural symbols. In recent years, genocide scholars have explored this idea of "genocide by attrition," that genocide is a process that can unfold over time, appear more or less destructive at difference stages, and encompass a wide range of methods. ${ }^{16}$ Silina writes that "there are more protracted, more ambiguously lethal means of extermination than machetes, guns or gas chambers. Many victims of historical genocides die from slower indirect and less immediately deadly methods of annihilation than outright murder." ${ }^{17}$ She believes that this idea of genocide as process, which is rooted in Lemkin's original concept of genocide, is actually more relevant to today's human rights abuses than the state-centric, totalitarian model endorsed by many scholars during the Cold War. Recent events in countries such as Darfur and Bosnia reveal more protracted campaigns of elimination that are messy, complex and often do not include a purely passive victim group. Yet just because members of a persecuted group, over a number of years, attempt to organize resistance, does not mean that genocide has not been perpetrated, Silina writes. She believes there is room for this multi-stage, process-oriented understanding of genocide in the emerging framework of international human rights law. ${ }^{18}$

During the European conquest of North America, disease was by far the greatest killer of native peoples. While specific intent to destroy the "family of mind" may have been present in certain acts of biological warfare - such as Lord Jeffrey Amherst's instructions that smallpoxinfected blankets be distributed among the Native Americans in order to "extirpate this Execrable Race" - Jones argues that more general intent could be applied to situations where natives were particularly vulnerable to disease due to overwork, malnutrition and forcible relocations. ${ }^{19}$ While, as mentioned before, Cold War understandings of genocide tended to be very state-centric, Tony Barta's conception of a genocidal society can be useful in analyzing colonial genocide. He writes that in such societies, even while the bureaucratic apparatus might purport to protect innocent people, "a whole race is nevertheless subject to remorseless pressures of destruction inherent in the very nature of the society. ${ }^{20}$ Thus, while authorities may have purported to undertake measures to safeguard Native Americans - and perhaps even harbored good intentions at times - the bottom line was that America's indigenous people were an obstacle to achieving the colonial European vision for the New World.

European conquest in North America was guided by a belief that the dying out of less civilized peoples was an inevitable byproduct of progress. This led many settlers to view the demise of native peoples with callous indifference. A "discourse of extinction" underpinned the logic of many settlers, Jones writes, and "under the influence of the most modern scientific thinking of the age, world history was viewed as revolving around the inevitable, sometimes lamentable supplanting of primitive peoples by more advanced and civilized ones." ${ }^{21}$ While not all settlers engaged in the outright killing of Native Americans, forcible relocation and increasing social marginalization prompted by settler society no doubt aided in the destruction of indigenous communities.

In Axis Rule, Lemkin outlined eight categories of genocidal strategies used by the Nazis, including "moral techniques." He argued that actions such as the encouragement of alcoholism and pornography in Poland could "'weaken the spiritual resistance of the national group." Through moral genocidal techniques, "the desire for cheap individual pleasure (would) be substituted for the desire for collective feelings and ideals based upon a higher morality."' 22 His concern with the moral and spiritual resources of social groups is apparent in his writings about conquered peoples

\footnotetext{
${ }^{16}$ Sheri Rosenberg and Everita Silina, "Genocide by Attrition: Silent and Efficient," in Genocide Matters: Ongoing Issues and Emerging Perspectives, ed. Joyce Apsel et al. (London: Routledge, 2013).

${ }^{17}$ Everita Silina, "Genocide by Attrition," International Affairs at the New School Working Paper, 2008, 1.

${ }^{18}$ Ibid.

${ }^{19}$ Adam Jones, Genocide: A Comprehensive Introduction, 2nd ed. (New York: Routledge, 2010), 114, 125.

${ }^{20}$ Tony Barta, "Relations of Genocide: Land and Lives in the Colonization of Australia," in Genocide and the Modern Age: Etiology and Case Studies of Mass Death, ed. Isidor Walliman et al. (Westport: Syracuse University Press, 2000), 240.

${ }^{21}$ Jones, Genocide, 106.

${ }^{22}$ Lemkin, Axis Rule in Occupied Europe, 90.
} 
and intoxicants. Alcohol introduced to the Tasmanians by settlers caused widespread addiction and even prompted men to sell their women for liquor. It undermined "the morals and health of the natives" and the high mortality rate of those banished to Flinder's Island "was partly due to their physical condition induced by drinking the liquor supplied them illicitly by the soldiers." ${ }^{23}$ Dutch colonists in South Africa often insisted on paying natives for their labor with alcohol and the introduction of liquor to these populations had a "deleterious effect upon them." ${ }^{24}$ Yet, despite his concerns about moral debasement, Lemkin realized that such strategies would be difficult to enshrine in law. ${ }^{25}$ Morality is not universal and, with intoxicants, a certain amount of agency was required of the native populations. Settlers continued to supply indigenous peoples with alcohol even though they were well aware of the harm it caused society - but native peoples also actively sought out liquor. Here, notions of group protection come into conflict with values of individual freedom and agency. As the case of the Native Americans will show, as long as indigenous peoples wanted alcohol, settlers were willing to provide them with it. Alcohol was a thriving business in early America, and the prospect of economic gain, combined with a general callous indifference toward the fate of Native Americans, led countless settlers to provide their indigenous neighbors with alcohol.

\section{Lemkin and the Alcohol Question}

According to Lemkin's multifaceted conception of genocide, the sale of alcohol to Native Americans was but one of many genocidal techniques. The substance undermined social functioning in a number of ways - through creating internal strife and violence, upsetting previous authority structures, causing premature deaths and eroding pre-existing cultural practices. A culture of drinking had not developed in Native American societies before the arrival of Europeans, and the intoxicants that did exist were used primarily for ritual purposes and strictly regulated by cultural mandates. Widespread consumption of alcohol, then, in Lemkin's view, would have certainly appeared part of the "imposition of the national pattern of the oppressor." Yet, while Native Americans may have learned to drink from Europeans, the ways in which their societies absorbed this practice led to particularly detrimental results.

In Lemkin's notes on alcohol and Native Americans, he emphasized the extent to which the substance undermined cultural functioning. Lemkin also focused on the amount of social strife alcohol caused. He drew much of his thinking from the 1825 work of John Halkett, "Historical Notes Respecting the Indians of North America: with remarks on the attempts to convert and civilize them," very much a product of its time. Paraphrasing Halkett, he wrote that Native Americans,

under the influence of intoxication will, in a fit of unbridled frenzy, murder friend, kin and even wife or offspring without distinction. (165). 'When the fit of insanity has passed, and the unfortunate wretch has recovered his reason, he laments in vain the misery which his own fury has entailed upon him; but while justly ascribes to the Europeans the blame of having supplied him with what caused such desolation, he will not scruple to seize the first opportunity of again obtaining it, and plunging with headlong fascination into new scenes of riot and bloodshed.' (165).

Author holds that I. intemperance was the immediate cause of many I. wars. I. retaliated for the havoc caused to their kin by the effects of liquor. In that manner whole tribes destroyed each other ${ }^{26}$

\footnotetext{
${ }^{23}$ Raphaël Lemkin, "Writings-Genocide," n.d., Raphaël Lemkin Papers, Manuscript Collection 1730, Manuscript and Archives Division, NYPL, Reel 3, Box 2, Folder 15, n.p.

${ }^{24}$ Ibid.

${ }^{25}$ Moses, Raphaël Lemkin, 37-38.

${ }^{26}$ Lemkin, North American Indians - Extermination, Card 11.
} 
While some of Lemkin's language may appear hyperbolic, he was correct in his assertion that alcohol led to significant violence and death in Native American communities. This was one of the main ways in which the substance undermined cultural functioning. As Malinowski writes, culture is supposed to fulfill the needs of the individual members of a group, including the basic need of protection. Binge drinking among Native American populations made individuals vulnerable to a number of different kinds of harm. Unrau lists several ways drinking led to increased mortality rates: exposure to the elements while intoxicated, intra-tribal violence, accidental death, increased vulnerability to disease. ${ }^{27}$ Records show that several Native Americans died with symptoms of bleeding from the mouth after consuming alcohol white settlers had laced with strychnine; the chemical "if administered sparingly, could enhance the inebriating force of alcohol dramatically" but when ingested in excess caused fatalities. ${ }^{28}$ Although lacing alcohol sold to Native Americans was a relatively common practice, no whites were prosecuted for this offense. At times, inebriated Native Americans also fell prey to sadistic colonists, who "'gave Indians liquor \& wen we were drunk killed us."' 29 In such cases of blatant homicide, colonial authorities often apologized to native communities and attempted to punish the perpetrators. Still, drinking continued to cause a great deal of violence, especially within Native American societies.

A foreign substance to Native Americans, alcohol by its very existence was a new pattern imposed on the New World by colonial settlers. The same was true of the ways in which alcohol was consumed. Because indigenous people had no significant experience with fermented beverages, and they were also largely unaccustomed to the effects of intoxication, they "learned about alcohol - specifically 'how to drink' - from scratch." ${ }^{30}$ Native Americans had no pre-established cultural guidelines for drinking, and the transient foreigners that they generally encountered often exhibited problematic drinking behaviors. ${ }^{31}$ Alcohol was ubiquitous in early America and, because of their social marginality, "Indians were exposed to persistent modeling of antisocial behavior associated with frequent high-dose drinking by soldiers, coureurs des bois (fur traders) and subsequently cowboys and miners - notably, all self-selected communities of men, away from their families and from the reach of alcohol policies and other forms of social control." 32 Regular drinking of hard liquor was prevalent in early America and laborers and soldiers were often given regular rations of alcohol; in 1830, adults over the age of 15 drank over an estimated seven gallons of spirits annually. ${ }^{33}$

While Native Americans may have initially learned patterns of heavy consumption from the whites they encountered, indigenous cultural beliefs about intoxicants may have also exacerbated destructive drinking practices in native communities. Before the introduction of alcohol, many communities of Native Americans had histories of attempting to reach mind-altered states in order to communicate with the spirit world. In pre-contact culture, "mind-altered states of the sort that presaged alcoholic inebriation post-contact were, in cultures such as that of the Plains Indians, associated with a quest for enlightenment, powers of healing, and the facilitation of war-making." ${ }^{34}$ Native Americans, in attempting to adapt to the introduction of a powerful new substance, interpreted the effects of inebriation within a pre-existing framework related to mindaltered states. Thus, they related "the new phenomenon of intoxication and aberrant behavior to the old concepts of dreaming, communion with the spirit world, and the acquisition of power." 35

\footnotetext{
${ }^{27}$ William Unrau, White Man's Wicked Water (Lawrence: University of Kansas Press, 1996).

${ }^{28}$ Ibid., 86.

${ }^{29}$ Peter Mancall, Deadly Medicine: Indians and Alcohol in Early America (Ithaca: Cornell University Press, 1995), 94.

${ }^{30}$ Genevieve Ames, et al., "Historical and Cultural Roots of Drinking Problems Among American Indians," American Journal of Public Health 90, no. 3 (2000), 345.

${ }^{31}$ Ames et al., Historical and Cultural Roots, 345.

${ }^{32}$ Ibid., 348.

${ }^{33}$ Unrau, White Man's Wicked Water, 2.

${ }^{34}$ Ames et al., Historical and Cultural Roots, 345.

${ }^{35}$ John Hamar and Jack Steinbring, Alcohol and Native Peoples of the North (Lanham: University Press of America, Inc., 1980), 3.
} 
This is one of the reasons they drank to the point of complete inebriation - the ultimate goal was to achieve an altered state of consciousness. ${ }^{36}$

Lemkin notes the ways in which colonial settlers used alcohol as a tool of conquest and manipulation. Fur traders soon learned that the indigenous people of the New World would trade even their most valuable possessions for rum, Lemkin writes. ${ }^{37}$ Again paraphrasing the work of Halkett, Lemkin describes the ways in which alcohol was used as a tool of influence during negotiations:

Similarly, the New England settlers, when welcomed by the great chief Massasoit in 1620, offered their host liquor of which 'he dranke a great draught that made him sweate all the while after.' (from a contemp.chronicle). It is assumed that Massasoit on this occasion acknowledged King James of Engl. as his sovereign. Similarly, the author supposes that when, in the following year, six other I. chiefs affixed their marks to a document - containing a like acknowledgement [sic], they did so under the influence of 'strong water. ${ }^{38}$

Numerous historical accounts demonstrate that an ongoing public dialogue continued regarding the destructiveness of alcohol in Native American communities, but little was done to remedy the problem. Some of the attention paid to Native American drinking was self-serving, as whites voiced concern over how drunk and violent Indians might threaten their own settlements. ${ }^{39}$ Europeans such as Benjamin Franklin used "discourses of extinction" in his descriptions of Native Americans and alcohol: "If it be the design of Providence to extirpate these savages in order to make room for the cultivators of the earth, it seems not improbable that rum may be the appointed means. It has already annihilated all the tribes who formerly inhabited the seacoast." ${ }^{40}$ As this passage shows, while Franklin was aware of the harm alcohol had inflicted on indigenous peoples, he thought their demise might be a historical inevitability, a sacrifice in the name of progress. America's settler population continued to expand, and to demand more land for cultivation. Some settlers even used alcohol to justify their seizure of Indian lands - since Native Americans could not control their insatiable thirst for liquor, they argued, they should be relocated even further from white communities, where alcohol would be less prevalent. ${ }^{41}$ However, wherever the Native Americans went, alcohol traders soon followed.

Native American leaders themselves appealed to colonial officials to stop the flow of alcohol. Little Turtle of the Miamis requested the assistance of President Thomas Jefferson to stop the sale of alcohol in Indian lands. In his remarks, he claimed that "When our white brothers came to this land, our forefathers were numerous and happy; but, since their intercourse with the white people, and owing to the introduction of this fatal poison, we have become less numerous and less happy." 42 Native American religious leaders and prophets also tried to convince their people to abstain from alcohol. The Delaware Prophet (Neolin) ordered Native Americans to "'abstain from drinking their deadly beson (medicine), which they have forced upon us, for the sake of increasingly their gains and diminishing our numbers."'43 Some of these prophets found success, such as Kenekuk of the Kickapoos. As a young man, he had killed his uncle in a drunken rage, but was later exposed to Christian theology, which he mixed with native spiritual beliefs and brought back to members of his tribe. He focused on the evils of alcohol, appealing to his people to give it up entirely, and told

\footnotetext{
${ }^{36}$ Ames et al., Historical and Cultural Roots

${ }^{37}$ Raphaël Lemkin, “North American Indians - Extermination," 1948-1949, Research Index Cards, Raphaël Lemkin Collection, AJHS, Box 9, Folder 13, Card 13.

${ }^{38}$ Ibid., Card 12.

${ }^{39}$ Mancall, Deadly Medicine, 26.

${ }^{40}$ William Szlemko et al., "Native Americans and Alcohol: Past, Present and Future," The Journal of General Psychology 133, no. 4 (2006), 439.

${ }^{41}$ Unrau, White Man's Wicked Water, 38.

${ }^{42}$ Ibid., 17.

${ }^{43}$ Mancall, Deadly Medicine, 116.
} 
them those who didn't "faced eternal damnation in the 'burning pits of hell."'44 After he began preaching, alcohol use declined considerably in his tribe and the community became more cohesive and productive. ${ }^{45}$

Authorities in America did indeed attempt to pass a number of laws restricting sale of alcohol to indigenous people, but they were consistently violated. The drive for profit, along with widespread settler beliefs that Native Americans were subhuman, prompted many whites to continue selling alcohol, no matter what the impact on indigenous communities. From the time of early contact with fur trappers, alcohol became a desirable trade good between whites and Native Americans. It could be transported long distances and was always seemingly in demand. Unlike a blanket, which would be bought once and not replaced for many years, quickly-consumed alcohol was always in need of replenishment.

Even once massive relocations of Native Americans began, alcohol continued to impact their communities. Hard-drinking frontier whites, living on the margins of society, willingly sold alcohol and "the white populace residing closest to the Indians and the tribal lands they so greatly coveted played the dominant role in supplying the Indians." ${ }^{16}$ Of course, it is hard to retroactively prove their motives, but along with economic profit, is it not possible that such settlers saw the destruction of Native Americans as a beneficial inevitability? The disappearance of this "inferior race" would open up more land for civilization and cultivation. The annuity payments made to relocated Native Americans led to increased access to alcohol. Traders made their way to the most remote reaches of Indian country and, as one regional authority reported back to Washington, "alcohol was 'as destructive and more constant than disease' in the depopulation of the western Indians. ... Whenever money is around it soon finds its way into the hands of the whiskey dealers, who swarm like birds of evil omen around the place where annuities are paid." ${ }^{\prime 7}$ Traders eagerly opened up lines of credit to Native Americans, and many became severely indebted. Few attempts were made to prosecute whites who illegally sold alcohol to Native Americans. (A similar situation existed in Australia, where whites were rarely held accountable for breaking laws prohibiting alcohol sales to aborigines, but aborigines were punished for drinking. ${ }^{48}$ ) American courts showed so little concern for the wellbeing of indigenous people that a Native American could maim or even kill another Native American in a drunken attack and face no fear of legal reprisal. However, the same situation did not hold for whites. In addition to aiding in the deterioration of native populations while financially profiting the colonial settlers, "the liquor trade became a crucible of culture in North America. Its persistence signaled a victory of British American values over those of Indian country." 49 Ultimately, a profit-driven European institution contributed to the dismantling of indigenous society. It seems this is very much what Lemkin had in mind when he referred to genocidal tactics that destroy "the national pattern of the oppressed group" and impose "the national pattern of the oppressor."

\section{"Intent" and the Problem of the "Drunk Indian"}

While the notes Lemkin assembled related to alcohol and indigenous people did indicate a strong argument for disruption of cultural functioning, two major problems arise with classifying distribution of intoxicants to natives of North America as "genocide" as he conceptualized the term. The first involves the question of intent, and the second the circulation of colonial discourses surrounding the figure of the "drunk Indian." In Lemkin's mind, while colonial settlers may not have initially understood the impact of alcohol on native populations, once its harmful effects became apparent, Europeans should have stopped its sale. According to Lemkin:

\footnotetext{
${ }^{44}$ Unrau, White Man's Wicked Water, 23.

${ }^{45}$ Ibid., 23.

${ }^{46}$ Ibid., 10.

${ }^{47}$ Ibid., 52.

${ }^{48}$ Sherry Saggers and Dennis Gray, Dealing with Alcohol: Indigenous Use in Australia, New Zealand and Canada (Cambridge, UK: Cambridge University Press, 1998), 47.

${ }^{49}$ Mancall, Deadly Medicine, 171.
} 
Later, when the full horrible effects of liquor on the Indian became widely known, when missionaries and secular disinterested whites tried to stop traffic, it continued unabated. Selfish greed and a cynical indifference to I. welfare, and in some cases perhaps the actual intent of sponsoring Indian self-destruction by such men as those who advocated the selling of infectuous blankets to I. (see cards of genocidists) must be imputed as motives of the guilty. ${ }^{50}$

Here, Lemkin ties alcohol sales to Lord Jeffrey Amherst's directive to distribute smallpox-infected blankets to Native Americans. While, given the widespread knowledge about the impact of alcohol on native communities, intentional destruction may have been the motive of some settlers; this would be exceedingly difficult to prove. If genocide, as defined by Lemkin, involves the disruption of culture with intent to destroy the national "family of mind," distribution of alcohol to native peoples remains an ambiguous case. Did settlers continue selling alcohol to natives with such an aim in mind? Or were they more driven by profit and a callous indifference to the harmful byproducts of their sales? Moreover, unlike actions such as forced relocations or the removal of children from their families, the alcohol trade flourished in Indian Country partly because Native Americans themselves sought out the product. Thus any harmful effects arose from actions on both the part of the settlers and members of the native communities.

Moreover, Lemkin's thinking on the subject may have been informed by colonial discourses that stereotyped the figure of the "drunk Indian." Quintero writes that colonialism controls not only physical space, but also the way we see others and how they perceive themselves. He acknowledges the destructive powers of alcohol, "how traders deliberately plied Indians with alcohol to facilitate exchange" or when "colonial officials made it a matter of policy to provide Indians with alcohol as part of a larger pogrom and assimilation campaigns." ${ }^{51}$ At the same time, he argues that discourses surrounding Native Americans and alcohol are a form of "intellectual colonialism." In early America, depictions of immoderate drinking among Native Americans indexed a supposedly decaying culture, and a people unable to cope with the modern world. To this day, the emphasis on drinking in Native American communities as problematic can cast indigenous people as weak or pathological. ${ }^{52}$ Lemkin may have had noble intentions in highlighting historical records that documented problematic drinking among Native Americans, but their focus on the inability of indigenous people to control themselves around the substance does potentially point to a form of intellectual colonialism that cast the oppressed as inherently weak.

\section{A Way Forward?}

While Lemkin's notes regarding Native Americans and alcohol did attempt to highlight one destructive strain of the colonial experience, he may not have given enough consideration to cultural adaptation and hybridity. He and others in the World War II period portrayed indigenous peoples as passive victims, completely overtaken by conquering cultures. Use of the term genocide, with "its implication of cultural or racial destruction and the connotation of finality do not sit well with current trends in the social history of indigenous peoples in the Americas that stress Native American persistence and continuity." ${ }^{53}$ Debates continue regarding the use of the word genocide to describe various aspects of the colonization of North America. The term has tremendous rhetorical power and has thus often been seized by communities in order to lobby for official recognition of past suffering and reparations. At the same time, Gone contends that the continued emphasis on historical trauma and genocide may not actually be productive for the future of native peoples. He argues for the restriction of the word genocide, solely to instances of mass killing, worried that too broad of an application diffuses the power of its meaning. ${ }^{54}$

\footnotetext{
${ }^{50}$ Lemkin, North American Indians- Extermination, Card 14.

${ }^{51}$ Quintero, Making the Indian, 6.

${ }^{52}$ Ibid.

${ }^{53}$ McDonnell, Raphaël Lemkin as Historian, 520.
} 
While it is important to note the resilience of native peoples, various acts of adaptation and defiance must be weighed against the far stronger forces of conquest - of a society that forced Native Americans from their land, extracted children from their homes and viewed their communities' decline with an air of inevitability. Alcohol played a significant role in this broader pattern of destruction, whether or not those who facilitated its distribution specifically intended to harm Native American communities or not. In addition to highlighting the physical destruction caused by the substance, it is imperative that scholars also engage with the myths surrounding its place in indigenous cultures. Continued problems with alcohol use in native communities are entangled with intellectual colonialism, as well as perceptions of historical use and biological susceptibility. It is only through confronting these legacies head-on that we can address continued patterns of detrimental alcohol use among native peoples of North America.

\section{Bibliography}

Ames, Genevieve, John Frank, and Roland Moore. "Historical and Cultural Roots of Drinking Problems Among American Indians." American Journal of Public Health 90, no. 3 (2000), 344-351.

Barta, Tony. "Relations of Genocide: Land and Lives in the Colonization of Australia." In Genocide and the Modern Age: Etiology and Case Studies of Mass Death, edited by Isidor Walliman and Michael N. Dobkowski, 237-251. Westport: Syracuse University Press, 2000.

Benvenuto, Jeff, Andrew Woolford, and Alexander Hinton. "Colonial Genocide and Indigenous North America." In Colonial Genocides in Indigenous North America, edited by Andrew Woolford, Jeff Benvenuto and Alexander Hinton, 1-28. Durham: Duke University Press, 2014.

Gone, Joseph. "Colonial Genocide and Historical Trauma in Native North America: Complicating Contemporary Attributions." In Colonial Genocides in Indigenous North America, edited by Andrew Woolford, Jeff Benvenuto and Alexander Hinton, 273-291. Durham: Duke University Press, 2014.

Hamer, John and Jack Steinbring. Alcohol and Native Peoples of the North. Lanham: University Press of America, Inc., 1980.

Irvin-Erickson, Douglas. Raphaël Lemkin and the Concept of Genocide. Philadelphia: University of Pennsylvania Press, 2017.

Jones, Adam. Genocide: A Comprehensive Introduction, 2nd ed. New York: Routledge, 2010.

Lemkin, Raphaël. Axis Rule in Occupied Europe. Laws of Occupation, Analysis of Government, Proposals for Redress. Washington: Carnegie Endowment for International Peace, 1944.

. "North American Indians-Extermination." 1948-1949. Research Index Notecards, Raphaël Lemkin Collection, American Jewish Historical Society, New York City, United States of America. Box 9, Folder 13, Cards 11-14.

. "Writings-Autobiography." n.d. Raphaël Lemkin Papers, Manuscript Collection 1730, Manuscript and Archives Division, New York Public Library, New York City, United States of America. Reel 2, Box 1.

"Writings-Genocide." n.d. Raphaël Lemkin Papers, Manuscript Collection 1730, Manuscript and Archives Division, New York Public Library, New York City, United States of America. Reel 3, Box 2, Folder 15.

Malinowski, Bronislaw. A Scientific Theory of Culture and Other Essays. Chapel Hill: The University of North Carolina Press, 1944.

Mancall, Peter. Deadly Medicine: Indians and Alcohol in Early America. Ithaca: Cornell University Press, 1995.

McDonnell, Michael A. and A. Dirk Moses. "Raphaël Lemkin as Historian of Genocide in the Americans." Journal of Genocide Research 7, no. 4 (2005), 501-529.

${ }^{54}$ Joseph Gone, "Colonial Genocide and Historical Trauma in Native North America: Complicating Contemporary Attributions," in Colonial Genocides in Indigenous North America, ed. Andrew Woolford et al. (Durham: Duke University Press, 2014). 
Moses, A. Dirk. "Raphaël Lemkin, Culture and the Concept of Genocide." In The Oxford Handbook of Genocide Studies, edited by Donald Bloxham and A. Dirk Moses, 19-41. New York: Oxford University Press, 2010.

Quintero, Gilbert. "Making the Indian: Colonial Knowledge, Alcohol and Native Americans." American Indian Culture and Research Journal 25, no. 4 (2001), 57-71.

Rosenberg, Sheri and Everita Silina. "Genocide by Attrition: Silent and Efficient." In Genocide Matters: Ongoing Issues and Emerging Perspectives, edited by Joyce Apsel and Ernesto Verdeja, 106-126. London: Routledge, 2013.

Saggers, Sherry and Dennis Gray. Dealing with Alcohol: Indigenous Use in Australia, New Zealand and Canada. Cambridge, UK: Cambridge University Press, 1998.

Siegel, Loren. “The Pregnancy Police Fight the War on Drugs." In Crack in America: Demon Drugs and Social Justice, edited by Harry Levine and Craig Reinarman, 249-259. Berkeley: University of California Press, 1997.

Silina, Everita. "Genocide by Attrition." International Affairs at the New School Working Paper, 2008.

Szlemko, William, James Wood and Pamela Jumper Thurman. "Native Americans and Alcohol: Past, Present and Future." The Journal of General Psychology 133, no. 4 (2006), 435-451.

Unrau, William. White Man's Wicked Water. Lawrence: University of Kansas Press, 1996.

Woolford, Andrew and Jeff Benvenuto. "Canada and Colonial Genocide." Journal of Genocide Research 17, no. 4 (2015), 373-390. 